\title{
The Changes of Women's Social Status Through Mesopotamia Myth
}

\author{
Wenzhao Qi* \\ Yunnan Minzu University, Kunming, China 650504 \\ *Corresponding author

\begin{abstract}
Ishtar is an ancient Mesopotamian goddess of fertility, war, and sex. As a female deity, she is neither an obedient wife nor a devoted mother, but an aggressive dominator and controller. Her persona, functions, and traits suggest that she would not be well-suited to affection or the stable bonds of marriage. She always destroys her lovers, which also brings difficulties to her own life. In mythology, Ishtar arbitrarily put her husband Dumuzi into hell and finally failed to revenge against Gilgamesh. The weakening of Ishtar's power reflects the decline of women's social status at that time.
\end{abstract}

Keywords: Mesopotamia myth, Women's social status, Ishtar

\section{WHO IS ISHTAR?}

\subsection{The Similar Goddess in Different Cultures}

Ishtar (Sumer pronunciation Inanna), also known as Ishtar (Akkad pronunciation Ishtar), is the most important and complicated goddess in the two river basins. She has many powers and great influence, and she is the leader in many myths and legends about the goddess in the world. She holds both heaven and earth, and is the god of Venus, Eros, and Goddess of War. Meanwhile, she is in charge of killing, reproduction, and regeneration.

In the book, The Treasures of Darkness (1976), Thorkild Jacobsen believes that Ishtar stands for these aspects of goddess - rain goddess, goddess of war, and goddess of the morning and evening, which has been recorded in Sumerian myth, Indian myth as well as Jewish myth[1]. Similarly, in the book, An Introduction to Ancient Mesopotamian Religion (2011), Tammi J. Schneider states that Sumerian Inanna is considered to be Ishtar in the Akkadian world. Also, Inanna is difficult to be separated from Ishtar because the two were linked somewhat early in Mesopotamian history [2]. That is to say, when studying this goddess, both of her identities should be considered, and the materials related to both identities could be used.

Regarding Ishtar's background, there are mainly the following views. One said that she was the daughter of the moon god Nanna-Sorn and the sister of the sun god Matthew. Another said that she was the daughter of Emperor Anu, but later became the wife of Emperor.

\subsection{The Goddess's Functions and Traits}

Ishtar/Inanna is a deity of fertility, a powerful goddess of love and war. Jacobson points out that the goddess Ishtar is a god representing infinite diversity, a goddess in charge of love, stars, fertility and war [3]. Her statues and portraits often contain a lot of elements, such as lions, long swords, arrows and scarves, red chalcedony, roses, anise stars and etc., which symbolize various meanings.

1. God of War.

According to the Code of Hammurabi, Hammurabi prayed that Ishtar's divinity would cause the enemy's military leaders to suffer disaster in wartime, and usually punish those who violated the code. The portrait of Ishtar mentioned above with arrows and swords, and the heroic attitude of leading a lion has already revealed her role as god of war. From her portraits, the elements of the lions and snakes, which have always shown people with majestic and powerful images, are lower than her height. The goddess Ishtar in the picture wears a spear and long sword on her waist, and a beam of arrows on her shoulders, which represents her war function.

2. The God of Star and Moon.

In each version of the image, the sun, moon and stars are her indispensable symbols. For this reason, some scholars believe that because Ishtar is the daughter of the moon god and the sister of the sun god, the gods of father and son, father and daughter, siblings, and husband and wife gods were inherited commonly in the mythology of the time. So, the Venus god is a symbol of Ishtar. Some scholars have also proposed that, the sun, moon and stars are closely related to the growth of all things in the world.

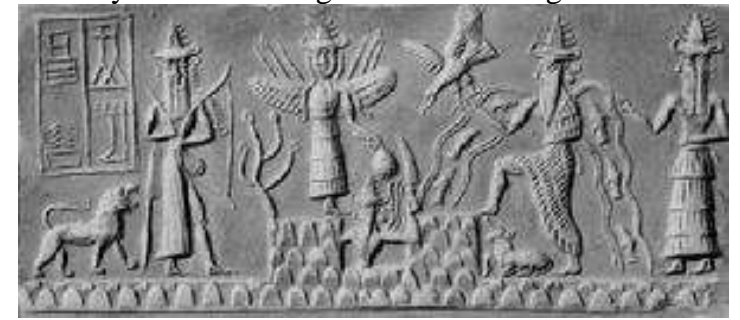

Ishtar's image is both "visible" and "thinkable" and "expressible". The intuitive details in the image narrative 
provide a concrete visible image, which itself also contains a deep social narrative space.

\subsection{The Role Conflict and Confusion of the Goddess Ishtar}

At first sight, there are some conflicts in the descriptions about Ishtar: How can love and war, which ate two contrary sides, be compatible in one goddess? Why as goddess of love, her disappearance can not cause any lamentation of her husband? How can a human king, Gilgamesh, refuse her proposal and frustrate her revenge even though she is the powerful goddess of war and the "queen of heaven and earth"? In addition to those failures, why does the goddess always destroy those she loves? These questions will be discussed in the following paragraphs.

\section{THE INTERPRETATION OF MYTH ABOUT ISHTAR}

According to Oxford English Dictionary, a myth is a traditional story, typically involving supernatural beings or forces, which embodies and provides an explanation or justification for something such as the early history of a society, a religious belief or ritual, or a natural phenomenon. Whether the aim of the Mesopotamia myths was only for pure entertainment is not sure, but the meaning behind the myths should not be overlooked. Maybe those myths provide some valuable views for people today. We explore the wisdom of the ancients, in order to understand the meaning they want to express.

\subsection{The Combination of Love and War: a Powerful Goddess}

Ishtar is the goddess of love. "Love" here does not mean aspects related to pity and kindness, but more related to adrenaline, hormones, passion, passion and sexual desire, which is consistent with the fertility function of the goddess. Survival and reproduction is the nature of human beings. Reproduction is one of the most important ways of survival. Only by achieving the sustainable reproduction of population can the production be better achieved. Thereby, providing the necessary population reserves for war and providing sustainable development for society. In the early society, women's reproductive function is not only a biological attribute of a living body, but also an important aspect of its social function. Women bear the important task of continuation and development of human society and play a crucial role in social production, so whether in secular society or in many myths, women are given a very high social status.

Why Ishtar is not satisfied with being the "Queen of Heaven and Earth", but also trying to seize the right to control the underworld from her sister? This is consistent with her traits as a goddess of passion and evil, she must continue to fight and aggress to meet her psychological needs to continuously obtain all resources. At the same time, it also renders and foreshadows the display of Ishtar's aspects of God of War.

For ancient people, sex and war are very important, because this is an important way to increase population and plunder resources. Sexual desire is considered a sacred force to ensure that gods, people, and all other creatures are maintained through generation's continuity. Therefore, social reality factors such as war and sex are often related to women, and they are presented as a complex of God of War and God of Love in the form of myth. As Engels said, "The goddess status in mythology and legend indicates that early women still enjoy a relatively free and respected status."

\subsection{Capriciousness under Anger: the Lost Goddess}

After Dumuzi became Ishtar's husband, he was given a lot of gold Silver wealth. Ishtar's encounter in the underworld, her husband Dumuzi did not show sorrow. When she was rescued from the underworld and returned, she meet her husband Dumuzi, she saw that he was wearing a gorgeous dress sitting on the throne and feasting on the throne, and did not mourn and weep for the death and doom of his wife. In anger, Ishtar relentlessly sent Dumuzi into hell. Faced with the sudden return of his wife and her angry, Dumuzi was very panicked and pale.

From which we can see that to Dumuzi, the wealth and status he received were all given by Ishtar, his wife. Although Dumuzi is a god, he cannot escape from Ishtar, once abandoned by his wife or refused to interpose with him, he will lose his divine power. This shows that the female represented by the goddess Ishtar is in a high position in that society, whether in political or economic status. Under the representation of the high position at this time, we can already catch some changes from it: Ishtar is still as strong as ever, but the attitude towards the powerful goddess has changed from the previous worship and respect to dissatisfaction, and even Dumuzi's pleasure after losing Ishtar.

\subsection{The Frustrated Proposal and the Revenge: the Goddess of Failure}

An important part of the myth is that Ishtar proposed to Gilgamesh and was rejected. Gilgamesh and his friend Enkidu jointly killed the weird Humbaba and rescued the goddess Ishtar.

The rejection of the marriage proposal made Ishtar feel extremely insulted and asked her father to give her the bull in the sky. She sent these bulls to punish Gilgamesh, but these bulls were killed by Gilgamesh and his good friend Enkidu. Enkidu even threw the bull's legs in Ishtar's Face. This is inexplicable for the powerful Ishtar, 
she does not understand that she is so powerful, why did the punishment for Gilgamesh fail? Under the characterization of the strong conflict between the two characters, perhaps a change is implicit: Ishtar and her symbolic strong feminism have gone, and the failure of Ishtar's revenge has made her gradually lose her status and influence. The reality of force has been further highlighted and strengthened.

\section{CONCLUSION AND DISCUSSION}

Ishtar is a very important goddess in ancient Mesopotamian religion, and people have a special worship for her. She has abundant adrenal vitality, passion and strong personality. She has both the bravery of God of War and the tenderness of Eros, but also the cruelty, greed and debauchery. These combined factors make her a powerful goddess. The failure of Ishtar's revenge shows the decline of the social status of Mesopotamia women in real society. Women's social status and changes are always an important issue for women's development, and they are always in a dynamic and complex process of change. Similarly, the social status of women in the ancient civilization of the two rivers is constantly changing, which is fully reflected in religious mythology and secular society. Among many creation myths in the two rivers Valley, many goddesses are in the gods, the status of the world continues to decline, and functions are gradually replaced by male gods. "Myth is not history, but in essence, myth is also true history, but this 'truth' is not the 'truth' of specific mythological characters and myth stories, the essential 'truth' hidden behind these representations. [4] " The fate of Ishtar and secular women is not just a coincidence. The decline of the status of women in the real society has led to the changes in the roles of the goddesses in the creation myth. The changes in the roles of Ishtar in the myth also reflect women's actual statues in the real society.

\section{REFERENCES}

[1] Thorkild Jacobsen, The Treasures of Darkness: A History of Mesopotamian Religion, New Haven: Yale University Press, 1976, 135-136.

[2] Tammi J Schneider, An Introduction to Ancient Mesopotamian Religion, Grand Rapids, MI: W.B. Eerdmans Pub, 2011, 60.

[3] Thorkild Jacobsen, The Treasures of Darkness: A History of Mesopotamian Religion, New Haven: Yale University Press, 1976, 136.

[4] Wu Tianming, "Research on Chinese Mythology", Beijing: Central Compilation Press, 2003 , 71. 